\title{
Family Matters in Racial Logics: \\ Tracing Intimacies, Inequalities, Ideologies
}

\section{Spike Peterson, Professor, University of Arizona}

\begin{abstract}
This article seeks to advance our understanding of how intimate relations and racial logics are co-constituted and matter-subjectively, culturally, materially and politically-in our colonial present of economic inequalities, nationalist populisms, anti-migrant discourses and xenophobic hostilities. Addressing these crisis conditions is urgent, yet critical interventions indicate that prevailing accounts inadequately address the scale, complexity and fluidity of racisms operating today. This article proposes to think racial logics 'otherwise' by drawing on interdisciplinary scholarship and intersectional analytics to produce a genealogy of state/nation formation processes, imperial encounters and legitimating ideologies that illuminates how 'intimacy builds (racialized) worlds' (Berlant 1998). A deep history of political centralization reveals that regulation of intimate, familial relations is a constitutive feature of successful state-making and crucial for understanding how modernity's 'race difference' is produced and how the racialization of 'Other' ('non-European,' undesirable) sexual/familial practices figures in contemporary crises. Locating intimate relations-'family'--in (birthright) citizenship, immigration regimes and political-economic frames helps clarify the amplification of global inequalities and the power of stigmatizations to fuel nationalist attachments and anti-migrant hostilities. Foregrounding intimacy and integrating typically disparate lines of inquiry advances our analyses of today's often opaque yet intense racisms and their globally problematic effects.
\end{abstract}

\section{Keywords}

inequality, state formation, colonialism, Eurocentrism, race/racism, sexuality, family, nationalism, birthright, immigration, citizenship

\section{Biography}

V. Spike Peterson is Professor of International Relations in the School of Government and Public Policy, and affiliated faculty in the Department of Gender and Women's Studies and the Institute for LGBT Studies at the University of Arizona. Her research interests include critical analyses of racialization, informalization, family/householding and global insecurities, as well as long histories and current critical queering of biosecurity, marriage, citizenship and states/nations.

V. Spike Peterson, University of Arizona

spikep@email.arizona.edu

\section{Introduction}

It is exactly the business of tracing and retracing contexts that puts things in a different light. ${ }^{1}$

On first sight, the intimacy of sexual relations may seem distant from racialized

\footnotetext{
${ }^{1}$ Teresa Brennan, Between Feminism and Psychoanalysis (London: Routledge, 1989), p. 12.
} 
violences, structural inequalities and global crises. But as Ann Stoler ${ }^{2}$ reminds us: 'To study the intimate is not to turn away from structures of dominance but to relocate their conditions of possibility and relations and forces of production.' I contend that tracing intimacies in contexts of state/nation formation puts a 'different light' on racisms operating in contemporary world politics. In this article I pursue two entwined questions: How do intimate relations-sexualities, marriage, family/household formations: henceforth, 'family'-figure in producing and perpetuating racial logics? ${ }^{3}$ And how do pervasive, destructive yet elusive racial logics shape inequalities, animosities and conflicts that directly and indirectly 'trouble' world politics, often as global crises? ${ }^{4}$

These questions are variously examined across disciplines, but International Relations (IR) has only minimally engaged the intimate: most often in relation to affect/emotion or sexualities ${ }^{5}$ and most recently in relation to racialized biosecurity and border policing. ${ }^{6}$ And

${ }^{2}$ Ann L. Stoler, 'Intimidations of empire', in Ann L. Stoler, (ed.), Haunted by Empire (Durham, NC: Duke University Press, 2006), pp. 13-14, emphasis in original.

${ }^{3}$ In this article I engage intimacy by foregrounding a constellation of sexual/familial relations-'family' (distinguished throughout by scare quotes)-that encompasses sensual, sexual and reproductive activities, conjugal and familial/kinship relations, and household sites of domesticity and resource pooling. Defining 'race' is notoriously problematic. I address varying aspects of this dilemma throughout the paper, but briefly here: I understand 'race' as a fluid category or 'mobile essentialism' emerging in early modernity and assuming varying forms and effects into the present. Ann L. Stoler, Duress (Durham, NC: Duke University Press, 2016), pp. 239-242. When referencing the modern era, I follow Stevens in preferring 'state/nation,' to emphasize the state's juridical power and how its formation precedes and produces national 'identifications.' See Jacqueline Stevens, Reproducing the State (Princeton, NJ: Princeton University Press, 1999), p. 43.

${ }^{4}$ Anna Agathangelou, 'Neoliberal Geopolitical Order and Value', International Feminist Journal of Politics, 15:4 (2013), pp. 453-476; Alexander Anievas, Nivi Manchanda and Robbie Shilliam, 'Confronting the Global Color Line: An Introduction', in Alexander Anievas, Nivi Manchanda and Robbie Shilliam (eds.), Race and Racism in International Relations (New York: Routledge, 2015a), pp. 1-15; Olivia U. Rutazibwa, 'From the Everyday to IR', Postcolonial Studies, 19:2 (2016), pp. 191-200; Millennium, 'Racialized Realities in World Politics', 45:3 (2017), pp. 267510; R. B. J. Walker, Robbie Shilliam, Heloise Weber and Gitte Du Plessis, 'Collective Discussion: Diagnosing the Present', International Political Sociology, 12:1 (2018), pp. 88-107.

${ }^{5}$ Roland Bleiker and Emma Hutchison (eds.), 'Emotions and World Politics', International Theory 6:3 (2014), pp. 490-594; Linda Åhäll and Thomas Gregory, Emotions, Politics and War (London: Routledge, 2015); Cynthia Weber, 'From Queer to Queer IR', International Studies Review, 16 (2014), pp. 596-601; Cynthia Weber, Queer International Relations (Oxford: Oxford University Press, 2016).

${ }^{6}$ Anna Agathangelou, M., Daniel Bassichis, and Tamara L. Spira, 'Intimate Investments', Radical History Review, 100 (2008), pp. 120-143; Michelle Richter-Montpetit, 'Beyond the erotics of orientalism', Security Dialogue, 45:1 (2014), pp. 43-62; Anne-Marie D'Aoust, 'Love as Project of (Im)Mobility', Global Society, 28:3 (2014), pp. 317-335; Joe Turner, 'Internal 
while few doubt that racial logics shape world politics, recent studies document IR's 'wilful silence' on race: founded in part to support white supremacy, disciplinary IR then suppressed questions of race and has failed to engage or advance critical analyses. ${ }^{7}$ I argue however that the intimacies of 'family' and the politics of 'race' are inextricable and that they mattersubjectively, culturally, materially and politically-in our troubled colonial present of economic inequalities, authoritarian populisms, right-wing nationalisms and xenophobic hostilities. ${ }^{8}$ As a corollary, I contend that we cannot adequately analyze or effectively address today's racialized crises without taking the entanglements of 'family' and 'race' seriously. IR is clearly ill-prepared to do so, which suggests the importance of thinking 'otherwise' and the urgency of engaging research that exists beyond--and marginalized within--the discipline.

Why urgency? Despite claims of a 'post-racial' world, the following suggest how race 'troubles' world politics and fuels global crises. ${ }^{9}$ Racial logics feature in a resurgence of neoimperial practices and amplification of Othering discourses that target 'undesirable subjects,' raise the stakes of Insider-Outsider claims (citizenship issues and border politics) and foster xenophobic scape-goating, expanded surveillance and 'enhanced' (bio)security measures. Racial politics operate in widespread intensifications of nationalist fervor, alt-right 'populist' movements and white supremacist activities, and in support of authoritarian leaders promoting discriminatory policies and cultural/heteropatriarchal/religious/racial demonizations of minority, non-normative and/or 'non-Western' populations. And racial logics figure in amplifying inequalities within as well as between nations, fueled by neoliberal restructuring and unprecedented concentrations of wealth, and in migration flows mobilized by increased poverty, loss of livelihoods, reduced access to basic needs, environmental degradation, militarized 'identity' conflicts and their production of asylum seekers and refugees.

IR scholars variously ponder these worrisome conditions, but rarely through a lens on intimacies, family relations and/or racial politics. Even increasingly frequent debates regarding the politics of Brexit, Donald Trump's presidency, climate change and populist movements typically neglect the power relations of 'family' and race when analyzing causes, complexities and effects of these troubling developments. ${ }^{10}$ With regard to theorizing global crises-and for

Colonization', European Journal of International Relations, 24:4 (2018), pp. 765-790; Joe Turner, Bordering Intimacy (Manchester: Manchester University Press, forthcoming 2020).

${ }^{7}$ Randolph B. Persaud and R. B. J. Walker, 'Apertura: Race in International Relations', Alternatives, 26:4 (2001), pp. 373-376; Alexander Anievas, Nivi Manchanda and Robbie Shilliam (eds), Race and Racism in International Relations (New York: Routledge, 2015b); Robert Vitalis, White World Order, Black Power Politics (Ithaca: Cornell University Press, 2015); Alexander D. Barder, 'Review Essay: Race and International Relations', International Studies Review, 19:3 (2017), pp. 509-516; see further below.

${ }^{8}$ By 'colonial present' I reference the uneven, tenacious, tangible and intangible continuities of colonialism in today's neo-imperial formations. See Derek Gregory, The Colonial Present (Malden, MA: Blackwell, 2004); Turner 2018.

${ }^{9}$ Extensive scholarship supports the following general claims; references in support of more specific arguments appear throughout the article.

${ }^{10}$ For example: Jasper Muis and Tim Immerzeel, 'Causes and consequences of the rise of 
well-rehearsed reasons--disciplinary IR remains focused on dilemmas of state sovereignty, international in/securities, and militarized conflicts. This selective vision stifles more adequate analyses by obscuring how subjective attachments and racist investments (intentional and otherwise) shape current developments. In a similar fashion, disciplinary theorizations of the state remain focused on 'realist' power, sovereignty issues and their economic coordinates. ${ }^{11}$ This effectively ignores decades of postcolonial, critical race and feminist scholarship that expands, complicates and enriches our knowledge of states, race, and 'family.' In this sense, disciplinary IR's dominant lenses effectively occlude how state/nations constitute and in/directly perpetuate sexual and racial logics and the social violences, and mounting crises, they foster.

On one hand, disciplinary IR's marginalization of feminist research generally, and studies of 'family' specifically, compromises its theorization of states. Briefly here, and key to arguments that follow, I draw attention to the requisites of state success that are widely assumed but rarely made explicit and hence are under-theorized. In brief, not all social groups presume or desire inter-generational continuity, or base membership on familial inheritance, or establish 'politically' significant (legally codified and sanctionable) Insider-Outsider distinctions. But states--as conventionally understood--do. State theorists variously acknowledge the salience of inheritable social status and property claims and assume that state success entails intergenerational continuity. Few however, take seriously how the centrality of inheritance and intergenerational continuity renders 'family' a focal site of power relations, with extensive, wideranging emotional, cultural and political-economic effects.

On the other hand, IR's compromised accounts of race and racism obscure the institutionalization of racial logics that David Goldberg ${ }^{12}$ casts as the 'racial state':

Race is integral to the emergence, development, and transformations (conceptually, philosophically, materially) of the modern nation-state. Race marks and orders the modern nation-state, and so state projects.... The apparatuses and technologies employed by modern states have served variously to fashion, modify, and reify the terms of racial expression as well as racist exclusions and subjugation.

populist radical right parties and movements in Europe', Current Sociology 65:6 (2017), pp. 909930; Economist, 'A dangerous waltz; European populism', 3 February 2018, pp. 33-34; Brent Steele and Alexandra Homolar, 'Ontological insecurities and the politics of contemporary populism', Cambridge Review of International Affairs, 32:3 (2019), pp. 214-221.

${ }^{11}$ Hendrik Spruyt, 'The Origins, Development, and Possible Decline of the Modern State', Annual Review of Political Science, 5 (2002), pp. 127-149; Scott F. Abramson, 'The economic origins of the territorial state', International Organization 71 (2017), pp. 97-130; Avidit Acharya and Alexander Lee, 'Economic Foundations of the Territorial State', American Journal of Political Science, 62:4 (2018), pp. 954-966. In an incisive, persuasive critique, Niang (2018) shows how IR's Westphalian conception of the state disregards contrasting forms and their histories, suppresses the importance and cultural aspects of securing legitimacy, and effectively compromises what we 'know' about contemporary states, stateness and 'non-states': Amy Niang, The Postcolonial African State in Transition (New York: Rowman \& Littlefield, 2018).

${ }^{12}$ David Theo Goldberg, ' Racial States', in David Theo Goldberg and John Solomos (eds), A Companion to Racial and Ethnic Studies (Oxford: Blackwell, 2008), pp. 233-258. 
Key here is the state's unique legal and sanctioning power regarding the production and 'management' of racialized categories, with direct and indirect, intended and unintended effects in racially differentiated practices, policies and outcomes. ${ }^{13}$

These points recall how disciplinary divisions thwart more holistic studies, not least by treating as if separate areas of inquiry that are inextricable in lived practice. This is importantly the case in scholarship delinking the study of states from the power relations of 'family' 14 and of race $^{15}$ (Goldberg 2008). A contemporary effect is inadequate theorizing of multiple inequalities and their problematic implications. I submit that the centrality of 'family' in state-making, the centrality of (racial) state/nations in IR, and the 'internationalizing' of racist politics warrant much closer and re-oriented attention if we are to more adequately address current challenges. ${ }^{16} \mathrm{I}$ therefore propose to put intimacies, 'family,' race and states 'in a different light' by retracing contexts of their historical, contingent production. In brief, I think racial logics 'otherwise' by drawing on interdisciplinary scholarship and intersectional analytics to present, in necessarily

${ }^{13}$ Thompson makes the following distinction: 'If racialism [the operationalization of race] concerns the fabrication of homogeneous social groupings, racism hierarchically orders those so marked, polices the boundaries that separate racial groups for possible transgressions and keeps those on the bottom from moving surreptitiously upwards without payment or punishment.' See Debra Thompson, 'Through, against and beyond the racial state', Cambridge Review of International Affairs 26:1 (2013), pp. 133-151.

${ }^{14}$ Tatjana Thelen and Erdmute Alber, 'Reconnecting State and Kinship', in Tatjana Thelen and Erdmute (eds), Reconnecting State and Kinship (Pennsylvania: University of Pennsylvania Press, 2018), pp. 1-35.

${ }^{15}$ Goldberg (2008).

${ }^{16}$ To be clear: my interest here is not in arguing 'for or against' states/nations, families, civilization or development -- as the costs, benefits and summary appraisals of each are rightly and intensely debated -- but in illuminating processes, practices and patterned effects of their historically contingent manifestations, especially those less familiar in IR. The arguments presented are part of a larger, on-going project that builds on extensive research already undertaken (genealogical work on social hierarchies, state/nation formation, global political economy) and more recent investigation of racial logics shaping nationalist populisms, antimigrant animosities and biosecurity practices. Only a schematic overview can be offered here; for more elaboration and additional bibliographic resources see my publications: V. Spike Peterson, 'Security and Sovereign States', in V. Spike Peterson (ed), Gendered States (Boulder, CO: Lynne Rienner Publishers, 1992), pp. 31-64; 'Sexing Political Identity/Nationalism as Heterosexism', International Feminist Journal of Politics, 1:1 (1999), pp. 21-52; A Critical Rewriting of Global Political Economy (London: Routledge, 2005); 'The Intended and Unintended Queering of States/Nations', Studies in Ethnicity and Nationalism, 13:1 (2013), pp. 57-68; 'Sex Matters: A Queer History of Hierarchies,' International Feminist Journal of Politics, 16:3 (2014a): 389-409; 'Problematic premises: positivism, modernism and masculinism in IPE', in Juanita Elias and Adrienne Roberts (eds), Handbook on the International Political Economy of Gender (Cheltenham, UK: Edward Elgar, 2018), pp. 23-36; 'Intimacy, informalization and intersecting inequalities', Labour and Industry, 28:2 (2018), pp. 130-145. 
broad strokes, a genealogy of state formation processes, imperial encounters and legitimating ideologies that illuminates both how 'intimacy builds worlds ${ }^{17}$ and shapes current racialized crises.

My account assumes a deep history perspective to reveal the codification of 'family' in the earliest state formations-the 'rise of civilization'-millennia ago. Foregrounding the requisites of state success and their hierarchical implications makes visible the production of structural inequalities as constitutive features of ensuring surplus production and inter-generational continuity. As described herein, the historical record shows that successful states regulate sexual reproduction (by legally codifying and enforcing intimate-'family'--relations), sustain surplus resource accumulation (by commanding labor and juridically regulating inheritance of property and status/citizenship claims), and cultivate identification with and allegiance to the state (by legitimating internal hierarchies and stigmatizing Outsiders: as inferior and/or threatening). As elaborated elsewhere, I argue that the early state's juridical (legal, enforced) regulation of reproductive sexual activities has the effect of producing 'sex' as a binary ('biological' malefemale difference); its management of resource accumulation produces stratifications of property ('class') and of social status (elite, citizen, free, laborer, slave); and its justificatory ideologies produce differential valorizations of Insider-Outsider (Self-Other, friend-foe, respectablethreatening). ${ }^{18}$

Moreover, I emphasize an unfamiliar point: that these inequalities are not, as generally assumed, separate or coincidental developments but constitutively intersecting as the state's definitive stratifications. I submit that analytically 'seeing' this intersectionality is essential for illuminating and more adequately theorizing the production of structural inequalities in subsequent (modern, contemporary) state/nation formations. A critical genealogy of these processes and reflection on their effects unsettles familiar narratives and, by putting things in a different light, enables 'thinking otherwise.' Importantly, it reveals how social categorizations of sex, class/status, and Insider-Outsider are historically produced and culturally, juridically (backed by state power) codified in ancient state-making processes, 'sedimented' (through writing technologies and legal codes) and naturalized by ideological legitimations of inequality that continue to shape our present. At the same time, understanding states as 'coercive enterprises ${ }^{19}$ problematizes the celebratory (modern, Eurocentric, developmentalist) narrative that casts state-making and 'the rise of (read: Western) civilization' as inherently 'progressive' human developments.

This genealogy of ancient states then affords a productive vantage point for tracing processes of modern state/nation formation. The latter occur in a quite different cultural, technological and political-economy context, where ideological legitimation of stark inequalities was paramount. Facing the increasingly blatant contradiction between liberal, Christian ideals and brutal practices of imperialism and colonialism, elites drew on nineteenth-century evolutionary narratives to 'rationalize' inequalities and European claims of superior development. I focus here on a biopolitical strategy of racialization: the state's construction of an

${ }^{17}$ Lauren Berlant, 'Intimacy', Critical Inquiry, 24 (1998), p. 282.

${ }^{18}$ Peterson (2014a).

${ }^{19}$ James C. Scott, Against the Grain: A Deep History of the Earliest States (New Haven: Yale University Press, 2017), p. 27. 
idealized template of (heteronormative, monogamous, Christian) marriage and family formation, and projection of this as a stark and unequivocal contrast to 'less developed' (unruly, uncivilized) practices of intimacy-cast as racial difference. ${ }^{20}$ Construing the intimate practices and familial relations of 'Others' as (racially) inferior effectively racialized both the stigmatized practices and the populations practicing them, ${ }^{21}$ while the practices being racially differentiated increasingly mapped on to 'territory of origin'--read: nationalist--distinctions. ${ }^{22}$

On this view, modern state-making again produced structurally intersecting inequalities of sex, social/class status, and Insider-Outsider. As noted however, the difference in historical context amplified legitimation issues. In this instance, states codified--juridically and culturallyheteropatriarchal marital and familial relations as a requisite regulatory mechanism, and at the same time--by claiming the racial superiority of white/European 'family'-as a social Darwinist legitimation of inequalities constituted by European imperialism and state/nation-making. The key point is how 'family' figures powerfully here, not only as a nexus of sexual and racial inequalities, but also as a requisite foundation for reproducing racial states.

And today? Europe's overweening imperial/colonial power enabled the construction of a world system based on (racialized) state/nations and 'ruled' by Western-centric ideologies and institutions, importantly including contemporary economic, citizenship, and migration regimes. IR scholars do not question how central, arguably decisive, these regimes are for shaping past and present world politics, as well as today's global crises. Yet they rarely examine how central, indeed definitive, 'family' is to all of these regimes, including how this shapes racialized inequalities, insecurities, and resentments that variously percolate through and foster global crises. $^{23}$

A primary aim of this article is to demonstrate that regulation of intimate, 'family' relations is a constitutive feature of successful (inter-generational) states, with myriad yet rarely examined implications for virtually all social relations in our current state-based world. An entwined aim is to illuminate how the inequalities made by states include asymmetric InsiderOutsider distinctions, which in modernity's imperial context are indexed as 'race difference,' with myriad implications for racialized crises in our colonial present. If these claims appear unfamiliar, I submit that this indicates how structural inequalities-here, heteropatriarchal sexism and racism--have effectively been normalized (depoliticized), and why a critical genealogy of

\footnotetext{
${ }^{20}$ George L. Morse, Nationalism and Sexuality (New York: Howard Fertiz 1985); Ann L. Stoler, Race and the education of desire (Durham, NC: Duke University Press, 1995); Anne McClintock, Imperial Leather (New York: Routledge, 1995).

${ }^{21}$ Deborah Chambers, A Sociology of Family Life (Cambridge: Polity, 2012); Sara McDougall and Sarah M. S. Pearsall, 'Introduction: Marriage's Global Past', Gender \& History 29:3 (2017), pp. 505-528.

${ }^{22}$ Stevens 1999; Srdjan Vucetic, 'Black banker, white banker', Cambridge Review of International Affairs 26:1 (2013), pp. 27-48.

${ }^{23}$ David Theo Goldberg, The Racial State (Oxford: Blackwell Publishers, 2002); Couze Venn, 'Neoliberal Political Economy, Biopolitics and Colonialism', Theory, Culture \& Society 26:6 (2009), pp. 206-233; Rogers Brubaker, Grounds for Difference (Cambridge: Cambridge University Press, 2015).
} 
their historical production is imperative. I caution that the expanse of terrain surveyed here necessitates a broad stroke, macro- orientation that over-generalizes what are always contingent, dynamic, divergent, complex and variously resisted inequalities and ideologies. I add that my 'history of the present' is intended as a provisional mapping, not a settled or definitive narrative. I hope however that it spurs 'thinking otherwise,' and especially troubles the conventional, problematic 'boundaries' of sex, gender, sexuality, family, race, states, nations and IR.

The article proceeds as follows. I first review definitional controversies and clarify my conceptualization of race. I briefly revisit burgeoning research on 'race and racism in IR,' which confirms the discipline's problematic engagement with racial issues and its inadequacy for addressing current crises. The next section develops a genealogy of state-making that begins with deep history, relies on interdisciplinary scholarship and develops intersectional insights. Tracing the earliest (ancient) state-making attempts reveals the definitive requisites of state 'success,' including regulation of sexual liaisons and production of intersecting inequalities. It also foregrounds how social categories of differential value are constituted, sedimented in ideological texts and variously continue to shape state-based political logics.

I build on this genealogy to trace entanglements of desire, sexuality, gender, race and nation in modern state/nation-making. The centrality of 'family' is legible here as both a strategy of sexual regulation and ideological legitimation (naturalizing Eurocentric superiority) in evolutionary terms: in effect, producing race difference and underwriting (racially) distinctive nationalisms. I then consider how racialized 'family' and Western-centric institutions shape contemporary state/nations, global governance and mounting crises. Sketching linkages among economic practices, racial logics and birthright citizenship reveals how state requisites shape troubling developments in our colonial present. I conclude that linking typically disparate lines of inquiry illuminates the racialization of 'Other' ('non-European,' undesirable) sexual/familial practices, the amplification of global inequalities, and the power of stigmatizations to foster an array of crisis conditions.

\section{Conceptualizing 'race'}

Racisms depend on indexes to mark differences made to matter,...Even in their formative moments, one finds a feverish search for tangible 'indices' of those intangibles that can't be seen or measured....Racism is protean. Essentialisms are always at work, but the features singled out as 'essential' don't stay the same. Diagnostics of difference change. ${ }^{24}$ Important here is Stoler's claim--shared by most contemporary critical race theorists--that criteria of race combine 'essentialized' and shifting features. ${ }^{25}$ Crucially however, Stoler emphasizes that 'essentialisms are secured not by the rote rehearsal of fixed traits but by their substitutable and interchangeable instantiations'; that a 'notion of essence rests not necessarily on immovable parts but on the strategic inclusion of different attributes, of a changing constellation of features and a changing weighting of them' ${ }^{26}$ For Stoler, it is precisely the adaptive capacity, the malleability ('mobile essentialisms,' 'polyvalent mobility') of features and combinations, and hence ambiguous relation of 'fixity and fluidity' that gives race its power and

\footnotetext{
${ }^{24}$ Ann L. Stoler, with E. Valentine Daniel, 'Interview', Public Culture, $23: 3$ (2012), pp. 487-508, emphasis in original (p. 492).

${ }^{25}$ Stoler (2016), p. 239.

${ }^{26}$ Ibid., pp. 261-262, 264.
} 
must be understood. ${ }^{27}$ This is not to dispense with the evocation of fixity (that 'underwrites racial logics') but to emphasize 'that racisms gain force precisely through the double vision they foster and allow'. 28

The merging of fixity (essentialisms) and fluidity (mutations) in considerations of 'race' clearly renders any definition controversial. In the context of endless and often fractious attempts to define race Anthony Marx $^{29}$ raises the "prior question of why race becomes salient at all....Race is not found but 'made' and used." This question re/directs inquiry to historical context and power relations shaping when, how, by whom and for what purposes race 'becomes salient,' or in Stoler's words, is 'made to matter.' A rich literature on race pursues this line of inquiry, examining how perceived social conditions (religious beliefs, labor regimes, 'embodied' difference, etc.) in one or another historical period 'best' explain the emergence of race and corollary racism/s. Doing so presumably clarifies (and for some settles) the meaning of race, understood as defining what features came to matter.

Some locate a 'coherent ideology of race' ${ }^{30}$ in the ancient world, from plentiful evidence of widespread slavery, antipathy to 'barbarians,' Aristotle's justification of enslavement, and the Greeks' categorical disparagement of Persians. Others site the origin of race in the feudal era of emerging capitalist relations, increasing religious conflicts and cross-cultural encounters. ${ }^{31}$ Increased exposure to cultural, linguistic, religious, and embodied differences raised 'categorizing' queries, not least how to distinguish 'humanness,' with implications for justifying, or not, practices of exploitation, enslavement, war and/or religious conversion. The long feudal period extended in to the early modern era of European imperialism and colonization, which in spite of continued resistances, increasingly realized the material and cultural devalorization, and often actual 'erasure,' of the West's 'Others.' My narrative locates race in this period of statemaking: in the context of European imperialism, its liberal contradictions, and justificatory ideologies. This view coheres with others who interpret race as a governing technology of 'life and death' ${ }^{32}$, an 'invention of modernity', ${ }^{33}$ a developmentalist ontology, ${ }^{34}$ inextricable from

${ }^{27}$ Ibid., pp. 261-262, 240.

${ }^{28}$ Ibid., p. 260.

${ }^{29}$ Anthony Marx, 'Race-Making and the Nation-State', World Politics, 48:2 (1996), pp. 180-208 (p. 180).

${ }^{30}$ Brent D. Shaw, 'Review of The invention of racism in classical antiquity', Journal of World History, 16:2 (2005), pp. 227-232; also Benjamin Isaac, The invention of racism in classical antiquity (Princeton, New Jersey: Princeton University Press, 2004).

${ }^{31}$ Cedric J. Robinson, Black Marxism: The Making of the Black Radical Tradition (London: Zed, 2000/1983).

${ }^{32}$ Michel Foucault, Society Must be Defended: Lectures at the College de France 1975-1976. Trans. David Macey (New York: Picador, 2004).

${ }^{33}$ Goldberg (2002).

${ }^{34}$ Arland Thornton, 'The Development Paradigm, Reading History Sideways, and Family Change', Demography, 38:4 (2001), pp. 449-465. 
modern nationalism, ${ }^{35}$ the colonial marker of 'persons' and 'sub-persons', ${ }^{36}$ and especially, as embodying the 'liberal paradox'. 37

Following Stoler and others, I understand 'race as a fluid, fragile and more or less vacuous concept ${ }^{38}$ whose power lies in its adaptive capacity, expressed as contextually fluctuating, ambiguous relations of 'fixity and fluidity.' This conceptual slipperiness poses specific challenges. First, the definitional malleability of 'race' both underpins its elusiveness and precludes unequivocally defining and/or empirically identifying 'race' and 'racism' in practice, or decisively 'locating' the period of its emergence. ${ }^{39}$ Second, while this malleability allows historical variation in which features are 'made to matter,' there is problematic continuity in how they matter: as demarcating superior from inferior and worthy from unworthy forms of life--and not only in Europe's colonial past but in our colonial present. Third, the demarcation of racialized populations presumably generates contextually varying but significant emotive, subjective effects. In this sense, racialization produces not only discernible and highly consequential cultural and material inequities, but also less visible yet powerful and consequential subjective 'attachments,' not least, to sexual, gender, cosmological, epistemological, nationalist and other political 'identities.'

These points highlight how elusive meanings and shifting criteria pose numerous questions: How and in what ways is the conceptual apparatus of IR adequate for addressing the shifting terrains of, and problems generated by, racisms operating in world politics? As biologistic 'markers' (appear) to lose credibility, which culturally coded 'differences' are 'made to matter' affectively and materially as racial criteria today? And how might postcolonial and feminist research advance IR analyses of and responses to racialized nationalisms, global inequalities, migration pressures and anti-migrant hostilities?

Given its disciplinary remit, IR is best positioned to examine 'the link between race as a structuring principle and the transnational processes of accumulation, dispossession, violence and struggle that emerge in its wake'. ${ }^{40}$ Yet the discipline has at various points been characterized as 'marginalizing race', ${ }^{41}$ being 'especially silent' on race, ${ }^{42}$ and cultivating 'racial

${ }^{35}$ Mrinalini Sinha, 'Nations in an Imperial Crucible', in Phillipa Levine (ed.), Gender and Empire (New York: Oxford University Press, 2004), pp. 135-155.

${ }^{36}$ Charles W. Mills, 'Decolonizing Western Political Philosophy', New Political Science, 37:1 (2015a), pp. 1-24 (p. 10).

${ }^{37}$ David Theo Goldberg, Racist Culture (Oxford: Basil Blackwell, 1993a).

${ }^{38}$ Ibid., p. 80 .

${ }^{39}$ For reasons given, I locate race in the modern era, but I do not dismiss alternative interpretations or presume a single, sedimented or 'fixed' definition of race.

${ }^{40}$ Anievas, Manchanda and Shilliam (2015a), p. 9.

${ }^{41}$ Roxanne L. Doty, 'The Bounds of "Race" in International Relations', Millennium 22 (1993), pp. 443-461 (p. 445).

${ }^{42}$ Persaud and Walker (2001), p. 373. 
aphasia': a 'calculated forgetting, an obstruction of discourse, language and speech' ${ }^{43}$ This 'habitual silence' however is being broken by a growing body of critical race scholarship that both documents and helps interpret the discipline's problematic engagement with racial issues. ${ }^{44}$

Historiographical studies reveal that questions of race and racism are not simply missing from but are integral to the field's development, indeed, constitutive of its founding and premises as a discipline. Emerging in a global context of imperial encounters and mounting racial tensions, IR was tasked with facilitating colonial governance and sustaining (white) Western hegemony. ${ }^{45}$ The problem however is not only the discipline's 'origin' as an imperial, effectively racist project and the 'willful forgetting' that this encouraged; it is also the arguably more extensive and enduring effects of '...the racist epistemological assumptions that inform much of contemporary mainstream and even critical analyses of world politics'. ${ }^{46}$ This involves not only

${ }^{43}$ Thompson (2013), p. 135.

${ }^{44}$ This scholarship appears not only in a surge of research publications but also in conference papers and panels, online forums and special issues (re)centering 'race in IR.' In the past decade an incomplete list includes Branwen Gruffydd Jones, 'Race in the ontology of international order', Political Studies, 56 (2008), pp. 907-927; Branwen Gruffydd Jones, 'Definitions and Categories', Postcolonial Studies, 19: 2 (2016), pp. 173-184; Sankaran Krishna, Globalization and Postcolonialism (Lanham, MD: Rowman \& Littlefield, 2008); Marilyn Lake and Henry Reynolds, Drawing the Global Colour Line (Cambridge: Cambridge University Press, 2008); Robbie Shilliam, The Black Pacific (London: Bloomsbury, 2015); Robbie Shilliam (ed), International Relations and Non-Western Thought (London: Routledge, 2010); Anna M. Agathangelou and L. H. M. Ling, Transforming World Politics (London: Routledge, 2009); James H. Mittelman, 'The Salience of Race', International Studies Perspectives, 10 (2009), pp. 99-107; Meera Sabaratnam, 'IR in Dialogue...but can we change the Subjects?', Millennium, 39: 3 (2011), pp. 781-803; L. H. M. Ling, The Dao of World Politics (London: Routledge, 2014a); L. H. M. Ling, 'Decolonizing the International', International Theory, 6:3 (2014b), pp. 579-583; Ida Danewid, 'White innocence in the Black Mediterranean', Third World Quarterly, 38:7 (2017), pp. 1674-1689; Disorder of Things symposia on books by John M. Hobson, The Eurocentric Conception of World Politics (Cambridge: Cambridge University Press, 2012), Shilliam (2015), Vitalis (2105); forums on 'race in IR', see International Studies Perspectives, 10:1 (2009), Cambridge Review of International Affairs 26:1 (2013), and on Hobson's 2012 book, see Postcolonial Studies, 19:2 (2016); a review essay by Barder (2017); and a special issue of Millennium, 45:3 (2017), pp. 267-510.

${ }^{45}$ Key texts include Vitalis's (2015) archival exposé of the discipline's racial past and complicities, and Hobson's (2012) examination of Eurocentrism and racism in an array of canonical IR thinkers (from 1760 to 2010), which '...paints a devastating picture of a field that simply amplifies the voices of the world's privileged and constantly finds new justifications for their advantage', Craig N. Murphy, 'It's the Economy, Stupid', in Ken Booth and Toni Erskine (eds), International Relations Theory Today (Cambridge: Polity Press, 2016), pp. 109-24 (p. $120)$.

${ }^{46}$ Alina Sajed, 'Race and International Relations', Postcolonial Studies, 19:2 (2016), pp. 168-172 (p. 168); also Siba N. Grovogui, Sovereigns, Quasi Sovereigns, and Africans (Minneapolis: University of Minnesota Press, 1996); John M. Hobson, The Eastern Origins of Western 
how European imperial, colonial practices--and cultural legitimations of these practices--shaped the emerging discipline's framing of foundational categories and methods, ${ }^{47}$ but also how (Eurocentric, 'rationalist') epistemological and ontological foundations shape the discipline's understanding and theorization of racial logics.

This growing body of work offers a vital opening; it has produced a wealth of historicalempirical studies and rich insights--and done so in the face of obdurate resistance. In further support of these projects, I advocate situating race (and racial logics) as a pre-eminent query and ongoing concern of the discipline. This follows from interpreting the modern state as both IR's central unit of analysis and, as Goldberg argues, a 'racial state':

States have acquired their modernity more or less and partially through racial assumption, through being drawn into the terms and forms, shapes and spaces, temporalities and rhythms of racial world ordering and world racial definition....As sets of institutions, and as ways of thinking and institutionalizing the governance of societies racial in both their metropolitan and their colonial expression, racial states emerged materially out of, as they were elaborated in response to, the "challenges" of colonial rule. ${ }^{48}$

To be clear: the point is not to reductively cast the modern state as a homogeneous, static and/or racist formation. It is to foreground (see further below) the imperial/colonial context and its liberal contradictions that so powerfully shaped both racial definition and modern state formation. Critical scholarship reveals the intellectual paucity of IR's engagement with race and at the same time, the urgent need to more adequately theorize how racial logics shape multiple and mounting crises. As one response, this article takes up the call to 'excavate and assess the extent to which received themes, concepts and theories commonly used in IR are indebted to the racial constitution of world order.... [and to provide] alternative theoretical/conceptual tools that are more adequate. 49

\section{Constituting 'civilization' and entwined inequalities}

Intimacy builds worlds. ${ }^{50}$

I explore what Lauren Berlant's insight might mean in today's world politics by tracing, in this section, the production of 'family' in the earliest state-making processes, and in later sections, the implications of 'family' in the production and practice of racial logics operating on a global scale.

The familiar narrative of 'human evolution' is most often cast as the 'ascent of man':

Civilization (Cambridge: Cambridge University Press, 2004); John M. Hobson, 'Is critical theory always for the white West and for Western imperialism?', Review of International Studies, 33 (2007), pp. 91-116; Hobson (2012); Alexander Anievas and Kerem Nicancioglu, How the West Came to Rule (London: Pluto Press, 2015; Rutazibwa (2016); Jones (2016); Mary E.

Hawkesworth, Embodied Power (New York: Routledge, 2016).

${ }^{47}$ Jones (2016), p. 173.

${ }^{48}$ Goldberg (2002), pp. 108-109.

${ }^{49}$ Anievas, Manchanda and Shilliam (2015a), pp. 10, 11.

${ }^{50}$ Berlant (1998), p. 282. 
from ape to human and from primitive to civilized. The story celebrates early centralizing processes as a 'natural evolution' of human-induced, linear and progressive stages. In this story the domestication of plants and animals (the 'agricultural revolution') afforded stable, large-scale settlements (the 'urban revolution'), and then processes of political centralization (stateformation) produced the socio-economic benefits of stable settlements and societal 'order' (civilization). Narratives celebrating 'progressive' human development gained stature and widespread attention as nineteenth century anthropological and evolutionary studies were publicized, and 'developmental' knowledge claims infused colonial, imperial and Eurocentric theory/practice. ${ }^{51}$ Importantly, the story's 'common sense' works to depoliticize (naturalize and normalize) the superiority claims of Western-centric beliefs, their elaboration in the evolutionary, developmental and liberal paradigms of 'human progress,' their prominence in Eurocentric IR, and their materialization in social Darwinist practices. Yet there are important reasons for critically rethinking this powerful story, not least that it is a self-serving tale promulgated by elites, and that its representation of 'states' and 'civilization' is increasingly disputed (see below). Exposing false claims in the story is a first (admittedly limited) step in eroding its normative Western-centric force.

Underpinning the celebratory narrative is a core assumption: that state-making, which enabled 'civilization,' was a revolutionary advance that humans 'naturally' preferred over conditions of gathering-hunting subsistence. But rather than welcoming the state, archeological research indicates that humans variously practiced plant and animal domestication for four millennia before 'the coalescence of agro-pastoral societies we have associated with early civilization' ${ }^{52}$ Scott writes that 'early states had to capture and hold much of their population by forms of bondage', that unfree, coerced labor 'appears to have been a condition of the ancient state's survival' and that until recent centuries, life outside of states-stigmatized as 'barbaric'afforded more leisure, freedom and better health than life under the 'domestications' of state rule. ${ }^{53}$ To make sense of these unfamiliar claims it helps to consider what state-making

\section{1}

Briefly: periodization locates the emergence of race in one or another 'era' of human history; developmentalism distinguishes temporally concurrent populations according to differentially valorized (superior-inferior, civilized-primitive) 'stages' of human development. See Thornton (2001); also on psychoanalytic framings of 'sexual development', see Neville Hoad, 'Arrested development or the queerness of savages', Postcolonial Studies, 3:2 (2000), pp. 133-158; on effects of human, not quite human and non-human statuses, see A. Wheleliye, Habeas Viscus (Durham, NC: Duke University Press, 2014); on developed, 'underdeveloped' and 'undevelopable' sexualized orders, see Weber (2016).

${ }^{52}$ Scott (2017), p. 58. Repressive features of state-making were earlier noted: see Gerda Lerner, The Creation of Patriarchy (New York: Oxford University Press, 1986); Michael Mann, The Sources of Social Power, Vol. 1 (Cambridge: Cambridge University Press, 1986); William H. McNeil, The Rise of the West (New York: The New American Library, 1991/1963), but Scott (2017) offers the most current research and comprehensive critique of conventional state narratives; see his Chapters 4 and 5 on the primacy of labor demands and extensive coercion in early, agricultural states. See Niang (2018) for an insightful and nuanced study of states, stateness and statelessness.

${ }^{53}$ Scott (2017), pp. xii, 30 and ch. 7. 
historically entails.

While virtually all discussions of 'the state' are controversial, there is considerable agreement regarding distinctive features of early (ancient) states: stable, centralized, elite control of material resources and political/juridical authority (enabled by writing technologies and coercive capacity); surplus production (enabling non-producing elites, ensured by stratified divisions of labor); regulation of sexual/familial/household arrangements and property claims (formalized in law codes and backed by state power); and legitimation of the new order (through revised cosmological narratives). ${ }^{54}$ Moreover, writing technologies (dominated by male elites) and revised cosmologies (displacing female-identified fertility in favor of male-identified deities and patriarchal authority) worked to naturalize asymmetric social categories, societal hierarchies and elite-produced narratives. One legacy is normalization of hierarchical, heteropatriarchal principles as foundations of societal order, reflected literally in the 'ascent of man' story celebrated in Eurocentric narratives. ${ }^{55}$

A close read of even this minimalist definition is instructive, as it reveals what the 'civilizing' story tends to conceal: that early state-making entails an unprecedented scale of coercive and stratifying practices that, if successful, institutionalize structural inequalities. Created and fomented by elites, the celebratory narrative and all but critical state theories tend to gloss over what successful state-making does, which is to consolidate, centrally manage, and enforce a socially stratified system. This is not to argue that status distinctions or inequalities are rare or inconsequential in non-state forms, where scholars acknowledge the presence of heterarchical relations ('fluid but orderly complexity that may or may not be ranked in a linear fashion'. ${ }^{56}$ But while 'hierarchies can exist within a heterarchy,..[none] is so dominant as to be able to subject the whole society'. ${ }^{57}$ What distinguishes early state formation is precisely the displacement (not elimination) of heterarchical relations by the dominance of hierarchical

\footnotetext{
${ }^{54}$ This depiction conforms to conventional accounts, see for example, Ronald Cohen and Elman R. Service (eds), Origins of the State (Philadelphia: Institute for the Study of Human Issues, 1987); Henri J. M. Claessen and Jarich G. Oosten (eds), Ideology and the formation of early states (New York : E. J. Brill, 1996); Barry Buzan and Richard Little, International Systems in World History (Oxford: Oxford University Press, 2000). On ideological legitimation see Henri J. M. Claessen and Peter Skalnik (eds), The Early State (The Hague: Morton Publishers, 1978), p. 14; McNeil (1991/1963), p. 51.
}

${ }^{55}$ On the significance of writing technologies see Jack Goody, The Logic of Writing and the Organization of Society (Cambridge: Cambridge University Press, 1986); Mann (1986); Lerner (1986); Peterson (1992, 2014a); Scott (2017), pp. 139-149. On (revised) cosmologies 'normalizing' asymmetric sex difference see Lerner (1986); Peterson (1992, 2014a); Peter N. Stearns, Gender in World History, $2^{\text {nd }}$ Ed. (New York: Routledge, 2006)); Diane L. Bolger, 'The Dynamics of Gender in Early Agricultural Societies of the Near East', Signs 35:2 (2010), pp. 503-531.

${ }^{56}$ Janet E. Levy, 'Gender, Heterarchy, and Hierarchy', in Sarah Milledge Nelson (ed), Handbook of Gender in Archaeology (Lanham, MD: AltaMira, 2006), pp. 219-246 (p. 220); see also Niang (2018).

${ }^{57}$ Charles Maisels, The Archeaeology of Politics and Power (Oxford: Oxbow Books, 2010), p. 16. 
stratifications that burden the majority. At the same time, practices of social control take new form in state-making where laws are 'impersonal' and enforced by the coercive power of the state.

A close reading also reveals that 'success' is far from 'obvious.' No state theorist denies that the register of state success entails inter-generational continuity. Yet few seriously investigate the implications of this for regulating either sexual reproduction or the transmission of property and social/political status claims. ${ }^{58}$ Doing so shifts attention to how social groups are constituted, reproduction (intimacy!) regulated, and insider allegiance and outsider exclusions cultivated. This foregrounds what the inter-generational success of states depends on: stabilizing elite, coercive control of resources; sustaining adequate population (by regulating sexually reproductive activities); ensuring surplus production (by compelling productivity and precluding subsistence alternatives), and cultivating identification with and allegiance to the state (by legitimating internal hierarchization and stigmatizing external groups). In early states, linguistic and socio-cultural differences figured in disparaging 'Outsiders. ${ }^{59}$ I argue below, however, that in modern states Insider-Outsider distinctions (read: emerging nationalisms), their attendant subjectivities and the intimacies of 'family'-especially sexual/conjugal/familial arrangementswere racialized.

The points assembled here suggest that state-making processes were complex and problematic. Understood as a 'coercive enterprise', ${ }^{60}$ early state-making marked a watershed in human relations: the institutionalization of social inequalities and corollary categories of asymmetric differentiation that writing materialized in law codes and justificatory cosmologies that endured through time. As noted earlier, I emphasize the unfamiliar but consequential point: these inequalities are not separate or coincidental developments but constitutively intersecting as the state's definitive stratifications. In other words, these inequalities -based on differential valorizations of sex, social/class status and 'Outsiders' ('Others')-operate inextricably to 'make states,' and states (by definition) are not made successfully if these structural inequalities are not simultaneously operating. However much the particular manifestations of each axis or modality vary (e.g., enslaved, bonded, waged, informal labor), they are structurally entwined as definitive features of state-making success. Recognizing this intersectionality has important methodological implications and enables more adequate understanding of inequalities in modern state/nation formation, and especially, the colonial racialization of 'family' and its continuing effects.

\section{Imperial intimacies and enduring legacies}

The state has the power...[to control] within the state...[and] exclude from state protection. In these senses, the modern state has readily lent itself conceptually to, as it has readily been defined by, racial (and gendered) formation...[These are]

\footnotetext{
${ }^{58}$ Exceptions include Frederick Engel's pioneering work, The Origin of the Family, Private Property, and the State (New York: Pathfinder, 1972/1884) and extensive feminist studies of patriarchal state theory/practice since the 1970s.

${ }^{59}$ Edith Hall, Inventing the Barbarian (Oxford: Clarendon Press, 1989); David Theo Golderg, 'Modernity, Race and Morality', Cultural Critique, 24 (1993b), pp. 193-227, (198-200); Stearns (2006).

${ }^{60} \operatorname{Scott}(2017)$, p. 27.
} 
processes aided integrally by...the law and policy-making, by bureaucratic apparatuses and governmental technologies like census categories, by invented histories and traditions, ceremonies and cultural imaginings. ${ }^{61}$

Attention to 'family' in ancient states makes visible constitutive features of stateformation that later effacements and normalizations render 'invisible'--as if they were 'givens of nature' rather than effects of political (power-laden) processes. In particular, the (Western, Eurocentric) 'common sense' understandings of (binary) 'sex' and heteropatriarchal family formation as natural (depoliticized and now normalized) are instead revealed as historically produced in early state-making processes and sedimented in law codes and revised (now patriarchal, hierarchical) cosmologies. ${ }^{62}$

Fast forward many centuries to another watershed transition in human relations: from the relatively decentralized conditions of the feudal era to the centralizing (Westphalian statemaking) dynamics of early modern Europe.$^{63}$ During the centuries in between, patriarchal authority was increasingly stabilized by male domination of textual productions and the expansion of monotheistic religions privileging masculinist, hierarchical principles. Intimacies of 'family' in the medieval era were more often shaped by varying local customs and religious traditions than 'politically' enforced law codes. Inheritance mattered primarily in relation to landownership, and among elites it was a 'way of consolidating wealth, transferring property, [and] laying claim to political power. ${ }^{64}$ And in the absence of territorially consolidated states and less formally defined boundaries, 'Insider-Outsider' distinctions had muted resonance, and 'exclusion and discrimination were religious at root, not racial' ${ }^{65}$ Modern state/nation-making, however, proceeded in the context of Europe's invasive 'explorations,' exploitations, colonizing practices, rising economic and military power, and self-promoting philosophical, political and religious belief systems. In short, competing elites in Europe were building empires, establishing territorial claims, codifying membership rules and constructing national 'identities.'

${ }^{61}$ Goldberg (2002), p. 9 .

${ }^{62}$ For research criticizing ahistorical ('naturalized') understandings of sex, sexualities, family, kinship, and social hierarchies see David Schneider, A Critique of the Study of Kinship. (Ann Arbor: University of Michigan Press, 1984); Robert A. Schmidt and Barbara L. Voss (eds), Archaeologies of Sexuality (London: Routledge, 2000); Sarah Franklin and Susan McKinnon (eds), Relative Values (Durham, NC: Duke University Press, 2001); Bolger (2010); Peterson (2014a); Helen M. Kinsella and Laura Sjoberg, 'Family Values? Sexism and heteronormativity in Feminist Evolutionary Analytic (FEA) research', Review of International Studies doi:10.1017/S026021051800044X.

${ }^{63}$ This and what follows are necessarily condensed and selective depictions of intensive, extensive and exceedingly complex processes, as well as wide-ranging and often contradictory literatures interpreting them. While integral, addressing how religion figures in producing and practicing racial logics is beyond the scope of this article.

${ }^{64}$ Stephanie Coontz, 'The World Historical Transformation of Marriage', Journal of Marriage and Family, 66:4 (2004), pp. 974-979 (pp. 976-977); see also Vivek Swaroop Sharma, 'Kinship, Property, and Authority', Politics \& Society, (2015), pp. 1-30; McDougall and Pearsall (2017).

${ }^{65}$ Goldberg (1993b), p. 202. 
Beyond disciplinary IR, postcolonial and feminist scholars, social anthropologists, historians and sociologists have for decades been mapping constitutive yet fluid and complex entanglements of desire, sex, race and power as materialized through imperial and colonial practices of exploration and exploitation. ${ }^{66}$ These studies expose manifold ways in which slavery, racialization and the sexual politics of empire reciprocally shaped both metropole and colonies. By attending to imperial intimacies, they illuminate and connect areas of inquiry not often foregrounded in IR scholarship. ${ }^{67}$ One focus is the making of nations and nationalist subjectivities, and the imbrication of race and gender in these processes. Another is a critique of racialized knowledge production and its continuing and contested effects. Especially targeted are Eurocentric narratives of developmentalism, ideological claims of 'evolutionary' superiority, and the political and economic arrangements implicated in subsequent concentrations of authority, power and resources among European(ized) elites.

I foreground here how elites 'legitimated' their increasingly coercive imperial and colonial practices, given the central contradiction of the era: on one hand, Enlightenment celebration of science, rationality, freedom and equality, and on the other, deepening penetration of state power into personal (intimate, 'family') relations in Europe and the unequal, often brutal practices of imperialism abroad. While European states commanded exceptional material power, direct coercion was too blunt, illiberal and costly a tool for sustaining imperial rule. In this context, cultural legitimation of new rules, rulers and inequalities was paramount for securing the continuity of a Eurocentric hierarchical order. As anthropological studies and evolutionary, developmental narratives gained prominence in the nineteenth century, European elites deployed them to legitimize empire's external and internal colonizations. ${ }^{68}$

As one key strategy of biopolitical management, European elites instituted-culturally and juridically--more restrictive sexual, marital and familial practices ('family'). ${ }^{69}$ In state-making

${ }^{66}$ Scholars conventionally cited include Franz Fanon; Edward Said; Gayatri Spivak; Partha Chatterjee; Ann Stoler; Paul Gilroy; Anne McClintock; Dipesh Chakrabarty; see further below.

${ }^{67}$ George L. Mosse, Nationalism and Sexuality (New York: Howard Fertiz, 1985); Nira YuvalDavis and Floya Anthias (eds), Woman-Nation-State (London: Macmillan Press, 1989); Etienne Balibar and Immanuel Wallersteing (eds), Race, Nation, Class (London: Verso., 1991); Ronald Hyam, Empire and Sexuality (Manchester: Manchester University Press, 1991); Andrew Parker, Mary Russo, Doris Sommer and Patricia Yaeger (eds), Nationalisms and Sexualities (New York: Routledge, 1991); Anne McClintock, Imperial Leather (New York: Routledge, 1995); Anne McClintock, Aamir Mufti, and Ella Shohat (eds), Dangerous Liaisons (Minneapolis: University of Minnesota Press, 1997); Nira Yuval-Davis, Gender and Nation (London: Sage, 1997); Stevens (1999); Phillipa Levine (ed), Gender and Empire (New York: Oxford University Press. 2004); Rogers Brubaker, 'Ethnicity, Race, and Nationalism', Annual Review of Sociology, 35:1 (2009), pp. 21-42; Barbara L. Voss and Eleanor Conlin Casella (eds), The Archaeology of Colonialism: Intimate Encounters and Sexual Effects (Cambridge: Cambridge University Press, 2012).

${ }^{68}$ Turner (2018).

${ }^{69}$ Points in this section build on Foucault's work (see especially Michel Foucault, Society Must be Defended: Lectures at the College de France 1975-1976. Trans. David Macey. (New York: Picador, 2004, Security, Territory, Population: Lectures at the College de France, 1977-78. 
terms, this served effectively as both a practice of regulation and an idealized projection of more highly evolved, hence (read: racially) advanced cultural practices. Specifically, Europeans increasingly formalized an idealized model of marriage that signaled 'white' (European) superiority: 'family' as heteronormative, patriarchal, monogamous, Christian matrimony and unequivocally 'respectable' sexual/familial relations domiciled in 'nuclear' households. ${ }^{70}$ This was projected as a stark contrast to the actual array of erotic, sensual, sexual, marital, familial and child-rearing practices that existed outside of Europe--and within it. Studies of biopolitical management within Europe are now abundant and document how the state's disciplining practices generated an increasingly rigid matrix of heterosexual-homosexual differentiation, masculinized public authority, feminized (private, affective) domesticity, a romanticized patriarchal 'bourgeois' household, and national identities invoking racialized superiority. ${ }^{71}$

Beyond Europe, an extensive critical literature documents how 'Other' (nonEuropean/non-white) practices-especially 'promiscuity,' polygamy, and non-heterosexual liaisons-were deemed inferior (primitive, less-evolved, undeveloped), characterized as markers of 'race difference,' constructed as threats to 'civilized' (orderly, respectable, rule-bound) societies, and denied legitimacy where they existed. ${ }^{72}$ Referencing earlier points and consistent with postcolonial critiques of Eurocentrism, this move effectively racialized 'difference' -construed as (racially) inferior intimate/sexual/conjugal/familial practices. ${ }^{73}$ The claim here is

Trans. G. Burchell. (New York: Palgrave, 2007), The Birth of Biopolitics. trans. Graham Burchell. (Houndmills: Palgrave Macmillan, 2008) and subsequent engagements with and revisions of it, including Goldberg (1993a, 2002); Stoler (1989, 1995, 2016); Elizabeth Povinelli, The Empire of Love (Durham, NC: Duke University Press, 2006); Venn (2009); Engin F. Isin, 'Citizens without nations', Environment and Planning D., 30 (2012), pp. 450-467; Turner (2018); Alison Howell and Melanie Richter-Montpetit, 'Racism in Foucauldian Security Studies', International Political Sociology, doi: 10.1093.

${ }^{70}$ As Deborah Chambers, A Sociology of Family Life (Cambridge: Polity, 2012), p. 16, emphasis in original, writes, "The aim was to prove that the acceptable version of monogamous marriage is the final, correct and highest stage of social evolution." Also Coontz (2004); Thornton (2001); McDougall and Pearsall (2017).

${ }^{71}$ This vast literature includes Mosse (1985); Wendy Brown, Manhood and Politics (Totowa, NJ: Rowman and Littlefield, 1988); Carole Pateman, The Sexual Contract (Stanford, CA: Stanford University Press, 1988); David Halperin, One Hundred Years of Homosexuality and Other Essays on Greek Love (New York: Routledge, 1990).

${ }^{72}$ See references in notes 66 and 67. Paraphrasing McDougall and Pearsall (2017), p. 515 : indifference to monogamous marriage became 'shorthand' for signaling 'inferior' people who 'could never be trusted.' Effects were especially stark--and enduring--in settler colonies, see for example, J. Marshall Beier, International Relations in Uncommon Places (New York: Palgrave Macmillan, 2005); Povinelli (2006); Scott Lauria Morgensen, 'Settler Homonationalism', GLQ, 16:1-2 (2010), pp. 105-131; Gurminder Bhambra, Connected Sociologies (London: Bloomsbury, 2014); Lisa Lowe, The Intimacies of Four Continents (Durham: Duke University Press, 2015).

${ }^{73}$ Stevens (1999); Povinelli (2006); McDougall and Pearsall (2017). 
that casting the intimate practices of 'Others' as racially inferior in effect racializes both the stigmatized practices and the groups practicing them. In other words, racializing practices of intimacy--'family'--effectively racializes populations perceived to be exhibiting stigmatized, 'inferior' sexual/familial customs, which I argue below figures powerfully but elusively in today's racial politics.

As depicted here, modern state-making formalized marriage as both a regulatory mechanism (as in early states) and--by claiming the superiority of white/European 'family'--a social Darwinist legitimation of inequalities constituted by state-making processes and European imperialism. These observations reveal not only how sexual and racial inequalities are entwined but also how 'family' is a focal site of power relations, both for (literally) reproducing the state/nation and for 'legitimating' internal and external hierarchies constituted by the (Eurocentric) racial state. I note as well that in modern state-making, the racial differentiation of 'people' mapped on to Insider-Outsider distinctions of nationalism. ${ }^{74}$

Finally, while modern state/nation-making regulated sexual relations in ways that effectively racialized populations, regulating 'family' also regulates inheritance of property and hence shapes economic inequalities. Insofar as 'unruly' sexual relations are politically and economically problematic, the state's regulation of 'family' is dual purposed: first, to codify a distinction between 'legitimate' and 'other' (non-conforming, inferior) sexual/conjugal practices, thus establishing state-sanctioned lines of descent; and second, to codify a distinction between state-sanctioned and local/religious/customary claims regarding property and social status, thus legally establishing lines of inheritance. These definitive features were consequential (see further below) both for transmission of citizenship claims (affording nationally differentiated prosperity) and accumulation of property and wealth (exacerbating within and between-nation inequalities).

In sum, the (Eurocentric) state's biopolitical regulation of 'family' and ideological legitimation of imperial inequalities were key in producing 'race' difference and the state's racial constitution: '...the power to exclude and by extension include in racially ordered terms, to dominate through the power to categorize differentially and hierarchically, to set aside by setting apart'. ${ }^{75}$ Requisites of state-making in modernity thus constituted inequalities of sex (now heteronormative, heterogendered), 'class' (both within and between state/nations), and InsiderOutsider (now racialized, nationalist differentiations). While perhaps unfamiliar, the claims in this section are supported by interdisciplinary scholarship (see earlier citations) and as I argue below, offer valuable resources for analyzing racial logics and power relations that trouble today's world politics.

\section{'Family' and racial logics in our colonial present}

Marriage has consistently operated in explicitly and implicitly racialized and gendered ways to control family formation, migration, health, and wealth. ${ }^{76}$

Once it is understood that the most fundamental structures of the modern state-the rules regulating marriage and immigration-are what enable the state to reproduce itself and what make possible the power relations associated with nationality,

\footnotetext{
${ }^{74}$ Stevens (1999); Goldberg (2002); Isin (2012).

${ }^{75}$ Goldberg (2002), p. 9.

${ }^{76}$ Dean Spade, 'Under the cover of gay rights', 37 N.Y.U. Rev. L. \& Soc. Change, 79 (2013), pp. 79-100 (p. 94).
} 
ethnicity, race, and family roles, then it is clear that piecemeal approaches to eradicating certain inequalities will not work. ${ }^{77}$

As claims of 'biologistic' race (appear to) lose credibility-yet virulent racisms continue-we are more than ever challenged to think 'mobile essentialisms attached to race' as less a matter of fixed, immutable referents than 'shifting criteria of assessments' including 'cultural competencies, moral codes, vague measures of civilities, emotive proclivities and sensibilities that [are] poorly secured by chromatic indices' (Stoler 2016, 240, 244-45). Hence, I foreground the racialization of 'family' not as a singular, decisive or stable framing of race but as important for identifying increasingly elusive racial/racist power relations operating in our (putatively) 'post-racial' present.

In the context of aggressive and growing alt-right nationalisms, anti-migrant and especially Islamophobic hostilities, I join critical voices to argue that the demonization of 'Other' (non-European, non-white, non-Christian) sexual/gender/familial practices is key to producing, structuring, and linking racialized and effectively racist citizenship and immigration arrangements and their problematic effects. Rather than earlier 'scientistic' and blatantly essentialist racist claims, justifications for discriminating against and materially excluding 'Others' today more often reference 'family' differences that stigmatize particular populations. For example: 'they are not 'like us" (categorically different, unassimilable, inferior); 'they have backward traditions' (lack 'development'); 'their marriages are arranged' (not modern, for 'love'), 'they veil women and deny them equal rights' (lack liberal, democratic values); and especially: 'they threaten civilized societies' ('inclusion' poses too 'contaminating' or dangerous a risk).

These discursive examples presumably evoke culturally varying mental images, typically however, without referencing physiognomic (biologistic, 'fixed') indices of 'difference.' Instead, demeaning characterizations of 'family' are alone sufficient to elicit emotional responses and fuel intense disparagements across symbolically, culturally and/or territorially delineated (read: 'nationalized') populations. In this way, sentiments and practices variously mobilized by racialized beliefs (about 'family') avoid appearing explicitly racist, yet continue to have (intended and unintended) racist effects. Paraphrasing Joe Turner, ${ }^{78}$ populations deemed incapable of, or unwilling to adopt, 'normal' intimate relations of 'family life,' or are 'attached to a traditional/backwards form of family' are too readily cast as 'threats to civilization' who need to be domesticated, developed or even eradicated.

While recognizing that the subjective and cultural aspects of racisms are intangible and hard to measure, I emphasize their crucial role in reproducing racisms: they reference the deep normalization (depoliticization) and internalization of ideologies promulgated by elites to naturalize the making of inequalities that burden the majority. We live not in a post-racial or 'color blind' world, but one where normalizations of inequality deflect critical inquiry, and intentional, explicitly racist attitudes and practices are variously decried or simply denied. As Goldberg writes '...post-raciality names the form of the social in and as a result of which racial expression proliferates, splinters, is multi-directional, multi-modal but from which it has scrubbed itself of explicit racial expression' (2016, 2280, original emphasis in original; see also Mills 2015b). While expressions may be less explicitly racist, it is critically important to situate

\footnotetext{
${ }^{77}$ Stevens (1999), p. xv.

${ }^{78}$ Turner (2018), pp. 782, 783.
} 
the production and expression of racial logics historically and materially, and for present purposes, specifically in relation to state-making's constitutive features and hierarchical effects. I attempt to do so in this section by tracing occluded power relations and overlooked institutional linkages, both to put things in a different light and reveal racial logics in the structural conditions of our colonial present. ${ }^{79}$

I first note key premises underpinning the necessarily condensed sketch that follows. From points made above, I assume that heterosexual, patriarchal and hierarchical principles (though never universal and variously contested) now dominate worldwide. Having instituted a state-based international system, Western-centric power and interests shaped the rules and practices subsequently structuring international relations, global governance, gendered and racialized divisions of labor, and capitalist, neoliberal and globalized economic arrangements. While appraisals vary, few doubt that the global North's domination of economic policies fostered and has variously exacerbated between-nation inequalities, which today exceed even the stark inequalities within many nations. ${ }^{80} \mathrm{I}$ have argued that successful state-making entails intersecting inequalities: initially of sex, resources, and Insider-Outsider differentiation; and in modernity of heteronormativity, gender, class, race and national differentiation. Importantly, I assume that racist ideologies and racial logics shape and are shaped by all of the following: the economic strategies generating a rich/minority/North and poor/majority/South, the inclusions and exclusions instituted by national citizenship rules and immigration policies, and the current amplification of nationalist populisms and anti-migrant hostilities. I have further argued that colonial racialization of 'family' mobilizes cultural criteria that foster us-them, Insider-Outsider distinctions that racialize 'nationalized' populations (whether territorial or not).

I turn then to how these premises underpin, shape, and link structural features of statemaking, contemporary inequalities, and global crises. In support of these claims I engage insights from typically disparate areas of inquiry--inheritance, citizenship, inequality, im/migration--to illuminate how dominant premises and observable, institutionalized practices interact and exacerbate global inequalities and crisis conditions today.

I begin by noting that (with relatively few, recent, and contextually specific exceptions) heteronormative, patriarchal principles of inheritance are the norm worldwide, and obviously key to accumulation, transmission and distribution of property and other valued resources. However varying in substance, legislatively codified rules of inheritance are backed by the power of the state and specify 'legitimate' marital, familial relations that determine both lines of descent and how resources are 'legally' transmitted. Inheritance promotes inter-generational continuity and unless interrupted, tends over time to amplify existing resource distributions. ${ }^{81}$

\footnotetext{
${ }^{79}$ Some of the following points overlap with arguments I develop in a different (global political economy) article currently under review.

${ }^{80}$ Branco Milanovic, Global Inequality: A New Approach for the Age of Globalization. (Cambridge, Massachusetts: Harvard University Press, 2016); Murphy (2016).

81 ' $[\mathrm{T}]$ he past tends to devour the future: wealth originating in the past automatically grows more rapidly, even without labor, than wealth stemming from work, which can be saved. Almost inevitably, this tends to give lasting disproportionate importance to inequalities created in the past, and therefore to inheritance'. See Thomas Piketty, Capital in the $21^{\text {st }}$ Century, trans. A. Goldhammer (Cambridge: Belknap Press, 2014), p. 378.
} 
These arrangements shape enduring inequalities, as state policies (regarding age, sex, race, etc.) codify both who can marry whom and how--through inheritance, taxation, welfare and family law--economic and other resources are accumulated and (re)distributed. One empirical effect is entrenched inequalities within and between state/nations that exacerbate harms, resentments and conflicts.

My focus here is how dramatically increased inequalities affect the politics of today's (racialized) migration patterns and responses to them. I argue elsewhere ${ }^{82}$ that migration is 'a family matter':

This connection is missed by IR and GPE scholars who ignore households and how their shifting (fluid, non-normative) realities affect international production, in/securities and migration strategies....Virtually all migrants strategize and act not as lone individuals but in relation to their participation in family/households, and their decision-making reflects not only economic concerns but also, for example, changes in sexual relations and gender roles, altered demographics and living arrangements, new reproductive technologies and eldercare options, and the complex unfolding of these in dynamic, increasingly global contexts.

With these points as background, I recall as well how states regulate not only intergenerational inheritance of material resources but also social status claims, including citizenship and the rights, privileges and resources (or not) thereof. This too is 'a family matter'-one that profoundly and interactively shapes individual lives and geopolitical hierarchies. To clarify: the vast majority of people acquire citizenship by birthright: being born on a nation's soil or of a citizen parent. ${ }^{83}$ 'Being born' entails some version of reproductive sexual interactions, and 'of a citizen' entails explicitly formalized 'familial' relations, with states determining whose marital, birth and parentage claims are 'legitimate.' These arrangements have wide-ranging but rarely interrogated implications for reproducing global inequalities. This is because birthright citizenship not only "shapes the allocation of membership entitlement itself...But...also distributes opportunity on a global scale." ${ }^{84}$ The crucial point here is that the principle of inheriting citizenship (through 'family') translates into inheriting the average income and 'life chances' in the country of birthright. As Ayelet Shachar writes, ${ }^{85}$ 'inheriting' citizenship in an affluent nation 'carries with it an immensely valuable bundle of rights, benefits and opportunities' that is effectively denied to the global majority-we might add, not because of anything the majority did or failed to do. In this sense, inheriting citizenship not only exacerbates

${ }^{82} \mathrm{~V}$. Spike Peterson, 'Family Matters: How Queering the Intimate Queers the International', International Studies Review, 16:4 (2014b), pp. 604-608 (p. 607).

83

Stevens (1999), p. 131; Ayelet Shachar and Ran Hirschl, 'Citizenship as Inherited Property', Political Theory, 35:3 (2007), pp. 253-287 (p. 254).

${ }^{84}$ Shachar and Hirschl (2007), pp. 254-255; Branco Milanovic, 'Global Inequality of Opportunity: How Much of Our Income Is Determined by Where We Live?, Review of Economics and Statistics, 97:2 (2015): pp. 452-460.

${ }^{85}$ Ayelet Shachar, The Birthright Lottery (Cambridge, MA: Harvard University Press, 2009), p. 5. 
global inequalities but does so by making citizenship a hereditary (ascriptive, morally arbitrary, 'unearned') entitlement; captured in Shachar's memorable title as The Birthright Lottery.

The expanding gap globally between haves and have-nots is widely acknowledged, with between-nation inequalities greater today than within even extremely unequal state/nations. According to the World Bank economist, Branco Milanovic, because the top-to-bottom ratio of mean national incomes is so extreme (more than 100:1), approximately $80 \%$ of inequality among global citizens is determined by national location (read: citizenship) alone. ${ }^{86}$ This unprecedented inequality has stark consequences for those 'located' in the poor/majority/South, who are both aware of these disparities and experience the harshest effects. An observable consequence is then enormous pressure for migration as the most promising strategy for improving the life prospects of individuals and families. ${ }^{87}$ Moreover, if permitted whenever desired, labor mobility would presumably over time shift all incomes toward greater equality. ${ }^{88}$

We know however that anti-migrant sentiments, policies and activities are expanding, and with troubling (racialized) effects. Im/migration policies of the rich/minority/North are increasingly selective about who (which citizens) and how many are welcome. This selectivity reflects both entrenched (ethnic, racial, economic) biases and more recent (cultural, religious, security) concerns. But whatever the justification, as Milanovic reminds us, ${ }^{89}$ constraints on $\mathrm{im} /$ migration that restrict population movements typically exacerbate inequalities between nations, as well as the insecurities, harms, resentments, conflicts and amplified migration pressures they engender. For good reasons, most critical studies focus on increasingly restrictive $\mathrm{im} /$ migration policies in the larger context of a 'migration crisis' and its social violences. But frequently overlooked, these inequalities increase not only as an effect of im/migration policies becoming more restrictive, but also as an effect of how states determine citizenship status (which involves state-sanctioned 'family' relations) and how citizenship status shapes (global) resource distribution and migration options. ${ }^{90}$ I refer again to 'citizenship as inherited property,' with 'profound distributive consequences [due to] relying on circumstances of birth in allotting political [state/nation] membership' (Shachar and Hirschl 2007, 253, 254).

Merging insights from typically disparate areas of inquiry--inheritance, citizenship, inequality, im/migration-illuminates under-theorized institutional linkages and indicates their racial premises. I emphasize here how states/nations define and confer citizenship and the juridical regulation of intimacy, marriage and familial relations this entails. If (national,

\footnotetext{
${ }^{86}$ See Branko Milanovic, 'Global inequality: from class to location, from proletarians to migrants', Global Policy, 3:2 (2012), pp. 125-134 (p. 129), who also addresses measurement debates.

${ }^{87}$ Milanovic (2012); Brubaker (2015), p. 159, fn. 11, cites global survey data (2009-2011) indicating $13 \%$ of the world's adults would prefer to emigrate.

${ }^{88}$ Milanovic (2012, 2016).

${ }^{89}$ Ibid.

${ }^{90}$ See Shachar (2009); Ayelet Shachar, 'Introduction: Citizenship and the "Right to Have Rights", Citizenship Studies, 18:2 (2014), pp. 114-124; Milanovic 2012; Piketty 2014; Brubaker 2015.
} 
racialized) citizenship (Milanovic's 'location') determines $80 \%$ of one's life chances, and birthright (involving state-sanctioned 'family' relations) determines citizenship, then 'family' becomes an enormously consequential site of critical inquiry in the context of global inequalities and their problematic effects. Stated differently, because (racialized) state/nation inequalities are so extreme, and immigration is so restricted, the intimate 'family' conditions of one's birth determine much more of individual 'life chances,' state/nation resources, between nation inequalities, and arguably, global crises, than conventionally recognized. Not least, birthright citizenship effectively locks individuals and their life chances into the conditions of one and only one (racially differentiated) state/nation. Rogers Brubaker observes that 'While discrimination on the basis of other ascribed identities has been massively delegitimated, discrimination on the basis of citizenship has been largely unchallenged....Citizenship [based on 'family'] is the great remaining bastion of strong categorical inequality in the modern world; this inherited status continues to underwrite and legitimate immense structures of between-country inequality on a global scale.' 91

These inequalities of course spur greater pressure on migration but also exacerbate harms, resentments and conflicts that variously trouble world politics. In sum, I am arguing that intimacy and 'family' matter for emotions and everyday lives, intersecting and racialized inequalities, state/nation politics and mounting global crises. For these and additional reasons, I submit that they warrant much closer and more critical attention within, and of course beyond, the discipline of IR.

\section{Concluding thoughts}

Racial regulation is reproduced through routinized governance of/over family, civil society, labor and markets....As much as power was cemented racially in state formations within a global ordering, resistance to any part of the racial ordering of states, affairs, and people ultimately has had to assume proportionate global reach. ${ }^{92}$

We live in a racialized world order with 'troubling' developments that the discipline of IR is uniquely positioned to address. The emergent literature on 'race and racism in IR' is thus vitally important: both for exposing a problematic history and expanding critical race studies in the discipline. I draw attention to this incisive research and urge much closer engagement with it. At the same time, I also note how the 'mobile essentialisms' of race and racism today pose unique challenges that require us to think racial logics otherwise.

As one response, I venture beyond the discipline's familiar terrain to foreground the centrality of 'family' in state-making and the making of race difference in modern states. My account draws on interdisciplinary scholarship and intersectional analytics to develop, in broad strokes, a genealogy of state formation processes, imperial encounters and legitimating ideologies that illuminates how intimacy builds (racialized) worlds. Framed by attending to both ancient and modern states, my genealogy foregrounds the production of inequalities--of sex, 'class' and Insider-Outsider--as mutually constituted and definitive stratifications of successful (inter-generational) state formation. This unfamiliar account disrupts celebratory claims regarding states and 'civilization,' with extensive implications for how we understand the production and practice of hierarchical social relations, including state/nations and the state-

\footnotetext{
${ }^{91}$ Brubaker (2015), p. 45.

${ }^{92}$ Goldberg (2002), pp. 117, 133.
} 
based international system. It also reveals that familiar inequalities have constitutively intersected from their earliest (Bronze Age!) codification, which makes, I believe, a powerful case for acknowledging this co-constitution and assuming an intersectional lens more widely when critiquing hierarchical relations.

Adopting intimacy as a lens enables a richer understanding of how affective attachments and investments-in heteropatriarchal principles and sexual, racial, cultural, national 'identities' and ideologies-shape the intensely emotive landscape of racialized issues in world politics; not least, nationalist populisms and anti-migrant hostilities. At the same time, situating the intimacy of 'family' in state/nation formation, citizenship logics, and political-economic frames advances structural/institutional understanding of how racial logics re/produce inequalities, insecurities and conflicts that are of disciplinary concern. One point here is how desire operates in the material construction of our social worlds; another is how this (again!) contradicts the binary logic of subjective-objective that persists in the discipline's marginalization of emotive, symbolic and cultural power. In contrast, I attempt a historical, interdisciplinary and intersectional account confirming how normalized beliefs, intimacy, subjectivity, emotion and the 'everyday' of cultural codes are inextricable from (mutually constitute) material, 'objective,' socio-economic, political and militarized manifestations of power. I contend that methodologically addressing this mutual constitution would significantly enhance IR's understanding of racial logics-and a great deal more.

My genealogy of state-making processes and account of racial logics is unfamiliar in IR. I argue that this is not because it is 'irrelevant' or lacks substantiation, but because our conceptual, disciplinary habits and colonial, Eurocentric investments occlude the centrality of 'family' in producing, normalizing and currently practicing racial logics. I intend my account to expand our understanding of sexual and racial logics, global inequalities, migration 'crises' and xenophobic (racist, nationalist) hostilities. And I contend that more seriously engaging these insights would advance not only IR knowledge of racial logics but also the discipline's relevance in addressing urgent concerns.

\section{Acknowledgements}

I am happily indebted to Aoileann Ní Mhurchú and Elena Barabantseva, whose innovative proposal and hard work enabled me to enjoy a Leverhulme Visiting Professorship (Grant VP22015-014) at the University of Manchester; and I am deeply grateful for all I gained from the critical conversations, research activities and fabulous company that the visit afforded. My thanks as well for a brief but similarly rewarding experience as a Richard Hodder-Williams Visiting Fellow at the University of Bristol. I truly appreciate feedback from readers of earlier versions and participants at many presentations of this research. Heartfelt thanks especially for the inspiring work and invaluable encouragement of Suzanne Bergeron, Laura Shepherd, Joe Turner and Cynthia Weber. Finally, my enduring gratitude to critical activists/scholars who, against the rising tide, persist in asking hard questions. 